\title{
Publisher Correction to: Global Health Research and Policy, volume 4
}

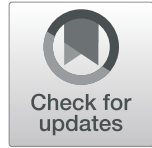

Global Health Research and Policy

\section{Publisher correction to: Global Health Research and}

Policy, volume 4

An error occurred during the publication of a number of articles Global Health Research and Policy. Several articles were published in volume 4 with a duplicate citation number.

In this correction article the old and new citation metadata are published in Table 1.

The original articles have been updated. The publisher apologizes for the inconvenience caused to our authors and readers.

Table 1 Overview of incorrect and correct citation metadata

\begin{tabular}{lll}
\hline DOI & Incorrect citation number & $\begin{array}{l}\text { Correct citation } \\
\text { number }\end{array}$ \\
\hline $10.1186 /$ s41256-019-0106-2 & 1 & 16 \\
$10.1186 / s 41256-019-0107-1$ & 2 & 18 \\
$10.1186 / s 41256-019-0108-0$ & 3 & 17 \\
$10.1186 / s 41256-019-0109-z$ & 4 & 15 \\
\hline
\end{tabular}

Published online: 09 August 2019

\footnotetext{
*Correspondence: info@biomedcentral.com
}

London, UK

Ready to submit your research? Choose BMC and benefit from:

- fast, convenient online submission

- thorough peer review by experienced researchers in your field

- rapid publication on acceptance

- support for research data, including large and complex data types

- gold Open Access which fosters wider collaboration and increased citations

- maximum visibility for your research: over $100 \mathrm{M}$ website views per year

At BMC, research is always in progress.

Learn more biomedcentral.com/submissions 